\title{
Amor e desejo: pequenas alegrias da vida adulta
}

\section{Fernando Bertolo \\ Nathalia Melati}

\section{AmarElo: considerações iniciais}

Z $m$ diversos pontos da cidade de São Paulo, jovens se reúnem em roda e E batalham entre si. Muitos deles usam bonés de aba reta, camisas largas, correntes douradas e só conseguem chegar ali depois de atravessar longas distâncias. Um dos jovens, com o microfone nas mãos, conduz a cerimônia. Ele pede para dois voluntários se dirigirem ao centro da roda para a primeira batalha, e pergunta à plateia: "O que vocês querem?", que responde: "Sangue!" É aí que um dos jovens começa a disparar rimas improvisadas sobre seu oponente, a ideia é desmoralizá-lo, diminuindo a sua imagem, enquanto exalta a si mesmo. A qualidade e a criatividade das rimas são cruciais para vencer, arrancar risos torna a vitória quase certa. E, o mais importante, a derrota é automática para quem não conseguir mais rimar.

O rap surgiu na década de 80 , e ganhou notoriedade em 97, quando os $\mathrm{Ra}$ cionais MC's lançaram o álbum "Sobrevivendo no Inferno". ${ }^{1}$ É uma das formas de expressão artística da cultura Hip-hop, junto com o DJ, o break e o grafite. Conforme Tella, é "produzido e consumido por jovens que moram nas regiões onde as tensões sociais e econômicas são latentes". ${ }^{2}$ Assim como tantos outros estilos musicais, o rap dá a voz a uma parcela da população que é silenciada de outras maneiras. As letras de rap nos mostram a identidade - quem se identifica com a realidade apresentada - e as paixões - quais emoções movem o auditório

1 Em 2018, a Unicamp (Universidade Estadual de Campinas) incluiu o álbum na lista de obras obrigatórias para o vestibular 2020

2 Tella, 2000, p. 7 
- desses discursos. São esses os três elementos da análise retórica de "Pequenas Alegrias da Vida Adulta", ${ }^{3}$ do Emicida, proposta por nós.

O rapper Emicida, Leandro Roque de Oliveira, começou a sua carreira nas batalhas de rimas. Assim como tantos outros artistas, as suas músicas retratam a vida das pessoas mais pobres e periféricas. Em Triunfo, ${ }^{4}$ seu primeiro single, lançado em 2008, Emicida evidencia as tensões mencionadas por Tella: "No morro a fila anda a caminho da guilhotina/ Vários queima de arquivo diária com a fome/ Vão amultuando os corpos de quem não tem sobrenome (...) Eu nasci junto a pobreza que enriquece o enredo/ Eu cresci onde os moleque vira homem mais cedo". Dez anos depois, e agora com uma carreira consolidada, Emicida lançou o álbum AmarElo, que possui um tom diferente dos demais, carregados de indignação. Em entrevista, ele afirmou que queria trazer calma à conturbada vida dos mais pobres: "A calma é revolucionária. E é a primeira coisa que roubam de nós". ${ }^{5}$ Aqui reside, em parte, o nosso interesse pelo álbum. Sabemos que todo discurso desperta paixões no seu auditório, mas há uma intencionalidade clara na criação de AmarElo.

No álbum, o auditório é instado a ver a indignação causada pela história do Brasil que oprime, repetidamente, o seu próprio povo. A resposta a esse sentimento não encontra eco, no entanto, em uma ação pelo ódio. O auditório é convidado a experimentar a calma como um antídoto, a respirar e pesar as suas decisões no cotidiano. As músicas discursam sobre a realidade das pequenas coisas, as alegrias das paixões despertadas nos entrelaces das vidas humanas. É um trabalho: "sobre se acalmar para poder pensar melhor". ${ }^{6} \mathrm{O}$ momento de lançamento do álbum nos remete a um contexto de polarização política, como uma ressaca de 2018, ano eleitoral, responsável por dividir famílias, amigos e colegas. De qualquer forma, sentimos as tensões geradas pela disputa política. Em AmarElo, cada uma das músicas se dedica a retratar novos elos possíveis com o outro frente a esse contexto. Optamos pela música que fala sobre o amor.

Sabemos o que é o amor porque já o experimentamos. Apesar de ser experiência coletiva, ele também é individual. Mães e pais repetem: "não há amor maior", mas completam: "você só vai saber quando for mãe (pai)". O amor parental, mesmo compartilhado por muitos, ainda é uma realização única porque gera um elo entre dois indivíduos. Esse elo nunca será igual a qualquer outro. Isso não impede, claro, que o amor parental, ou o conjugal, seja representado

3 Emicida, 2019a. Apenas no YouTube, o clipe da música já foi reproduzido mais de 3 milhões de vezes, o que atesta sobre a eficácia do discurso

4 Emicida, 2008

5 Emicida, 2019b

6 Ibid. 
em produções artísticas. Ao lado da experiência individual, então, há sempre uma representação de amor que, normalmente, atende a valores, virtudes e comportamentos aceitos socialmente. Reconhecemos, além disso, a presença de uma disputa discursiva que envolve essas representações. $\mathrm{O}$ amor é fruto de crenças e valores sociais.

Ao definir o amor, Bauman ${ }^{7}$ o descreve a partir da morte. Os dois, para o autor, são únicos e definitivos quando se realizam. Não é possível repetir a chegada da morte e do amor. Não se experimenta o mesmo amor, ou se morre, duas vezes, são eventos únicos a cada realização. Assim, não há um passo a passo que leva ao amor ou à morte. Para Bauman, não é possível aprender a amar ou a morrer. A observação desses eventos quando ocorrem com o outro não nos torna melhor preparados para lidar com eles em momento oportuno. Nem mesmo aquele que já se apaixonou diversas vezes está mais apto a "fazer o certo" na próxima.

Martuccelli, ${ }^{8}$ por sua vez, compreende que a proximidade com a morte alça o amor a um ideal da vida humana, como também o são a nacionalidade, o trabalho e a religião. O três últimos, segundo o autor, são ideais em crise na sociedade. Em contrapartida, há cada vez mais pessoas que vivem por amor. Econtrar, manter, desfrutar desse amor prometido é hoje a força motriz da vida de milhares de pessoas. Esse novo ideal não é, no entanto, louvado pelo autor. Segundo ele, a igreja, o Estado e o trabalho funcionam como suportes para a existência coletiva, enquanto o amor é individual. Mesmo como ideal, "algo pelo qual as pessoas estão dispostas - ou dizem estar dispostas - a morrer", 0 amor só se realiza no encontro com o outro. A busca pelo amor é, assim, individual, os amantes encerram-se em si mesmos, distanciam-se do mundo.

Já Bauman questiona qual amor a sociedade privilegia. O amor é definido como "o impulso criativo e como tal carregado de riscos, pois o fim de uma criação nunca é certo". ${ }^{10}$ Para conquistar esse amor, é necessário a coragem e a humildade: "Essas duas qualidades são exigidas, em escalas enormes e contínuas, quando se ingressa numa terra inexplorada e não mapeada. E é a esse território que o amor conduz ao se instalar entre dois ou mais seres humanos." ${ }^{11}$ Para o autor, a definição romântica do amor - "até que a morte nos separe" - aos poucos perde força na sociedade, e caminhamos para compreender o amor como

7 Bauman, 2004

8 Martuccelli, 2016

9 Martuccelli, 2016, p. 147

10 Bauman, 2004, p. 21

11 Ibid., p. 22 
"experiência amorosa". A mudança de significado em curso é uma das marcas de uma sociedade com base no consumo. O sentido do amor, assim, se enfraquece.

Bauman opta, então, por separar o amor em dois. Há um amor verdadeiro, aquele que nos impulsiona a criar; e o desejo. Enquanto um gera, o outro é impulso de destruição. Amar é cuidar, preservar o objeto cuidado. O desejo, em contrapartida, aniquila o outro. Ainda segundo o autor, o desejo é despertado pela mera presença do outro. "A presença da alteridade", por si só, já o aciona.

Desejo é vontade de consumir. Absorver, devorar, ingerir e digerir aniquilar. O desejo não precisa ser instigado por nada mais do que a presença da alteridade. (...) O desejo é um impulso que incita a despir a alteridade dessa diferença; portanto (...) a provar, explorar, tornar familiar e domesticar. ${ }^{12}$

A todas as características do desejo, o amor se opõe. O amor e o desejo surgem a partir do encontro com o outro. Aceitar o outro, com humildade e coragem, parece ser o caminho do amor, enquanto o desejo se resume a vontade de domesticar as diferenças. A linha entre eles, no entanto, é tênue. "Amar significa estar a serviço, colocar-se à disposição, aguardar a ordem." ${ }^{13}$ Se exacerbada, essa proteção do outro pode se realizar em cercear, aprisionar. Amar, então, também se traduz como possuir o outro. Bauman declara o amor e o desejo irmãos, muitas vezes gêmeos, e confundir um pelo outro é parte da nossa cultura.

"É numa cultura consumista como a nossa, que favorece o produto pronto para uso imediato, o prazer passageiro, a satisfação instantânea, resultados que não exijam esforços prolongados" que construímos "a 'experiência amorosa' à semelhança de outras mercadorias". ${ }^{14}$ Faz parte do nosso modo de vida consumir por impulso. O consumo envolve, necessariamente, duas etapas: "usá-los [os bens] e descartá-los em seguida a fim de abrir espaço para outros bens e usos". ${ }^{15}$ Acumular bens não significa ter uma casa atulhada de coisas, mas ter a capacidade de se desfazer delas e comprar novas. Não há, então, espaço para o impulso de criação pertencente ao amor. Parece-nos que não temos acesso ao tempo exigido pelo amor.

Bauman propõe, assim, que a fragilidade dos nossos laços e a cultura consumista nos compelem a entender o amor como "experiência amorosa". Lembremos

12 Bauman, 2004, p. 23-24

13 Ibid., p. 24

14 Ibid., p. 21-22

15 Ibid., p. 69 
que o amor surge do nada, como a morte, para o autor. Não se pode refazer os seus passos. Quando o amor equivale à "experiência amorosa", no entanto, ele pode ser replicado porque apresenta uma realização muito clara: a relação sexual. Evidencia-se, novamente, em Bauman duas versões do amor, uma digna e virtuosa; e outra mundana, entregue ao desejo. E a última é, como argumenta o autor, naturalmente cultivada pelo nosso estilo de vida. Consumimos o amor como tantos outros bens: usamos, descartamos, abrimos espaço para um novo.

Essa separação do amor também está em Martuccelli. Apaixonar-se é hoje a maior promessa de felicidade do sujeito. $\mathrm{O}$ amor representa uma possibilidade de felicidade para todas as pessoas, ou, ao menos, partilhamos a crença de que o amor é para todos. Se o amor encontrado, segundo o autor, no entanto, for o mundano, os amantes apenas encontrarão como resposta: "a insignificância da vida [que] é, com intensidade sem precedentes, o destino e o grande desafio de significado de nossa era". ${ }^{16}$ Essa posição reforça a concepção de um amor virtuoso e um vil. Além disso, é interessante notar que a busca pelo amor é tida também como a busca pela felicidade. ${ }^{17}$

Tomemos, para compor as reflexões sobre o amor, o diálogo "O Banquete" de Platão. O texto narra um banquete entre Sócrates, Erixímaco, Aristófanes, Fedro, Alcibíades e outros. Na ocasião, como haviam se embriagado na noite anterior, os presentes decidiram passar o tempo definindo o que é o amor. Sócrates, que não participara dos festejos da noite anterior, não se opôs. Assim, cada um dos presentes declama "o mais belo discurso em louvor de Eros", ${ }_{18}$ "deus tão antigo e poderoso, [que] jamais teve uma homenagem (...) composta por um único poeta entre tantos que já existiram". ${ }^{19}$

Fedro, o primeiro a discursar, descreve Eros como um grande deus. A sua graça é tão poderosa que, na busca por uma vida feliz, o desejo por posição social ou riqueza são pequenos frente à felicidade que o amor traz. Aquele que ama, que é digno da graça de Eros, torna-se tão virtuoso e valoroso que seria capaz de morrer por seu amor. O orador, dentre seus exemplos, cita Alceste, que se ofereceu para morrer no lugar do seu marido Admeto, rei de Feras. Ainda que ele tivesse pai e mãe, apenas a esposa se sacrificou por amor. $\mathrm{O}$ ato foi tão nobre que os deuses devolveram sua alma ao mundo dos vivos. Quem é digno da graça de Eros torna-se virtuoso e valoroso porque é capaz de morrer por amor. Quando nos sacrificamos por amor, conclui o orador, recebemos a admiração dos deuses por tamanha virtude e nos tornamos também divinos.

16 Martuccelli, 2016, p. 163

17 Fim último do homem, conforme Ferreira (2020), também em Inteligência Retórica: o Pathos

18 Platão, 2010, p. 41

19 Ibid., p. 40-41 
Pausânias, o segundo a discursar, reconhece a existência de um Eros divino, mas acredita também haver um Eros mundano. O primeiro é elevado e nobre, é virtuoso, e toma como objeto de seu amor a alma de um indivíduo. Já o segundo é mundano, por isso o objeto de seu amor é a forma física. Como ela é transitória, o Eros mundano só resulta em tristeza e decepção. Para Pausânias, o amor mundano, aleatório, é vil e prejudicial à ordem social, e deve, portanto, ser cerceado por leis sociais. Erixímaco, o médico, concorda em seu discurso com a visão de "dois Eros". E acrescenta que a força do amor não age somente sobre nós, mas está presente em toda a natureza. Eros é um desejo cósmico que busca harmonizar os opostos. Quando este desejo é realizado com comedimento, a vida se desenvolve de forma saudável, ou seja, ela se multiplica. Quando não há controle do desejo, criam-se desequilíbrios, como as secas e as pragas.

Os últimos oradores antes de Sócrates apresentam discursos curiosos. O primeiro, Aristófanes, é escritor de comédia. Ele narra que éramos seres compostos por quatro pernas, quatro braços e dois sexos. Zeus, irritado com a nossa pedância, teria nos dividido. O amor, como desejo erótico, é então uma carência original em busca de união e plenitude. Aristófanes sugere ainda que, se continuarmos a irritar os deuses, Zeus nos separará novamente, obrigandonos a pular em uma perna só. O discurso acrescenta, em certa medida, humor à ocasião. $\mathrm{O}$ anfitrião toma, então, a palavra e profere um discurso elogioso que não pretende definir Eros, mas louvá-lo. Agaton descreve Eros como um deus astuto, um hábil caçador, um grande técnico, um experiente viajante que penetra imperceptivelmente nas almas. Eros não pede satisfação a ninguém, e também são os deuses afetados por seus desígnios. O louvor a Eros no discurso foi tamanho que os presentes irromperam em aplausos.

Sócrates é o próximo orador. O filósofo reproduz uma conversa com Diotima, de Mantinea, uma sábia versada nas artes eróticas com quem aprendeu sobre o amor. Para ela, Eros é um daimon, nem deus, nem homem, mas algo intermediário que medeia o humano e o divino. Eros é filho de Poros, a personificação divina do recurso, e de Penia, personificação da penúria, portanto é astuto como o pai e carente como a mãe. Quando Eros se manifesta nos humanos, coloca neles um desejo pela imortalidade. Esse desejo se realiza de duas formas. A primeira é pela forma física, que se expressa pela geração de filhos. Ainda que sejam mortais, os filhos representam um momento de perpetuação, ou seja, de imortalidade. Se não filhos, pode-se também gerar com a alma. É o desejo pelo conhecimento. A busca ao conhecimento está, assim, atrelada a um impulso erótico que nos leva a amar a beleza das ideias e o próprio belo. Esse desejo, que é virtuoso, quando alcançado gera uma virtude. Aquele que possui uma virtude é, então, tão imortal quanto ela.

Ao final do discurso, narra-se a chegada de uma figura destoante ao jantar. Alcibíades, um poderoso estratego (general) grego, chega completamente bê- 
bado e, ao invés de louvar a Eros como fizeram os outros, faz um discurso em que declara seu amor a Sócrates. Ao relatar conversas com o sábio, Alcibíades louva as suas virtudes. Ele alerta o auditório: se ouvirem os seus discursos também serão arrebatados por suas palavras. Conforme pontua Nussbaum, enquanto os outros se dedicaram a tentar definir o amor, Alcibíades relata "uma história de paixão complexa, tanto sexual como intelectual, por um indivíduo particular". ${ }^{20}$ Em meio a tantos discursos sobre um Eros virtuoso e divino, o último discurso propõe um desafio aos presentes por trazer uma história de amor. Desta forma, ele nos recorda que o amor, além de virtudes dignas da admiração divina, também se expressa na tragédia cotidiana, mundana.

Não há, em "O Banquete", ${ }^{21}$ uma definição final sobre Eros. Há reflexões acerca do amor e seu significado. A dualidade do amor, no entanto, se repete nos discursos pela separação entre o Eros nobre e divino; o mundano e passageiro. Temos dois tipos de amor: o virtuoso e o vil. O primeiro é tido como o amor digno da graça de Eros; é o amor divino, verdadeiro, real, multiplicador. É por esse amor que trocamos a nossa vida - bem maior - pela vida do outro. Já o segundo é mundano, efêmero, desequilibrado e destrutivo. Por se ater às aparências, é o amor que não sobrevive o passar dos anos, o envelhecimento dos corpos. Essa divisão, entre virtuoso e vil, também se faz presente, como visto, nos autores modernos.

A definição do amor a partir da morte (ou da escolha pela morte), a divisão do amor em dois, um virtuoso e outro vil, e a promessa de felicidade pelo amor estão, então, tanto em Platão (2010) quanto em Bauman (2004) e Martuccelli (2016). Os últimos acrescem ao debate, primeiro, com reflexões acerca da cultura do consumo e, segundo, com a concepção de amor como ideal de vida. Como vimos, o amor é capaz de impulsionar para a criação, a multiplicação, a manutenção da vida, mas também pode destruir, consumir e aniquilar. Aristóteles ${ }^{22}$ também escreve sobre o amor. Não propriamente como sensação, mas como uma das paixões despertadas no auditório pelo discurso.

\section{As paixões aristotélicas: fundamentação teórica}

A Retórica se debruça sobre a potência da palavra. Desde os escritos de Platão e Aristóteles, buscamos entender o peso da palavra na construção e na manutenção da vida em sociedade. As relações humanas são construídas e mantidas pela interação discursiva, é pela palavra que expressamos opinião,

20 Nussbaum, 2009, p. 147

21 Platão, 2010

22 Aristóteles, 2000 
crença, valores e marcamos quem somos perante os outros. Por isso, definimos, conforme Meyer, a "retórica [como] a negociação entre indivíduos - ethos e pathos - sobre uma questão $(\log o s)$ que os divide em maior ou menor grau, ou que pretende abolir, ou pelo menos diminuir, as suas distâncias". ${ }^{23}$

Como disciplina, foi sistematizada no livro Retórica de Aristóteles, embora esse não seja o primeiro texto a citá-la. Em Górgias, ${ }^{24}$ por exemplo, Platão já descreve um diálogo entre Sócrates e Górgias, renomado orador, em que debatem se a Retórica deve ou não ser considerada como arte, ${ }^{25} \mathrm{o}$ que comprova a discussão anterior sobre o tema. Aristóteles abre seu tratado respondendo, justamente, a essa pergunta. Para o autor, todos fazem uso da argumentação para discutir e defender teses, para defender ou acusar; e indagar por que alguns obtêm êxito, e outros não, constitui "a função de uma arte". ${ }^{26}$

Aristóteles exemplifica as provas adequadas aos oradores, a depender do seu objetivo, a partir de casos reconhecidos pelo seu auditório. O autor se debruça sobre como persuadir um auditório, mas também sobre o que é a palavra e o raciocínio lógico. Hoje, os estudos retóricos não descartam os postulados por Aristóteles, Platão e tantos autores, mas antes reconhecem a eficácia dos discursos modernos a partir de uma teoria expandida por autores como Perelman e Olbrechts-Tyteca (2014); e Meyer (2017). No entanto, fazemos hoje, como parte da análise, o caminho inverso. Realizamos leituras retóricas que reconstroem a utilização dos meios de persuasão que se mostraram adequados àquele discurso. Com isso, buscamos entender como a negociação de distâncias entre os indivíduos se constrói pelas interações discursivas.

Aristóteles define dois meios de persuasão: os independentes da arte retórica e os que são construídos e supridos por ela. Os independentes são o testemunho e a evidência, como a mancha de sangue na cena do crime. Não há necessidade de se construir pelo discurso a veracidade dessas provas. Já os meios que dependem da arte retórica devem ser criados pela palavra. Um bom orador faz uso de três provas retóricas, de acordo com o que é adequado ao discurso. É pela imagem do orador, construída pelo discurso, que o auditório se identifica com o seu caráter. A persuasão pelo ethos é obtida com as virtudes despertadas pelo discurso. As paixões também podem ser evocadas para conduzir o auditório

23 Meyer, 2017, p. 6, tradução nossa

24 Platão, 2016

25 Conforme Puentes (1998, p. 129): o espectro semântico recoberto pelo termo grego téchne é muito mais abrangente do que o que a sua tradução mais usual, arte, significa para nós. Isto ocorre porque ele não se refere apenas e tão somente à habilidade ou destreza de um especialista qualificado capaz de produzir com maestria algum artefato, mas também a uma dimensão teórica e especulativa. Em outras palavras, a téchne, portanto, é para os gregos uma forma de conhecimento 
a uma ação. Por dividir (ou assim desejar) as mesmas qualidades do orador, o auditório é instado por uma paixão. Com isso, o discurso, o logos, se apresenta (ou assim parece) como real. O auditório se posiciona em relação ao discurso, ao se identificar ou não com as virtudes, as paixões e os argumentos apresentados.

As paixões - dentre elas o amor - "são todos aqueles sentimentos que, causando mudança nas pessoas, fazem variar seus julgamentos, e são seguidos de tristeza e prazer, como a cólera, a piedade, o temor e todas as outras paixões análogas, assim como seus contrários". ${ }^{27}$ Ainda para o autor, as paixões são acompanhadas por dor ou prazer, são parte do mundo sensível, das sensações. Meyer, ao buscar em Platão a definição de paixão, adiciona que a sua origem está no princípio passivo da alma humana, representada como "animais atrelados, conduzidos por um cocheiro que tenta harmonizar os puxões dos cavalos que se lançam em direções opostas". ${ }^{28}$ A contraparte da paixão, princípio passivo, está na ação, princípio ativo. Entregar-se aos puxões dos cavalos da paixão gera uma ação tanto quanto resistir a eles. A diferença está entre resistir ao apetite sensível ou não.

A cólera, a inveja, o amor, a vergonha, a compaixão, a indignação, o desprezo, as paixões afetam o nosso julgamento de maneira geral. Os discursos buscam, naturalmente, despertar paixões no auditório a partir das escolhas do orador. Para poder selecionar as paixões eficazes ao seu discurso, o orador precisa criar uma imagem do auditório. O pathos, então, é a imagem do auditório criada pelo orador. Não é fiel ao auditório, em si, mas a representação que o orador tem desse auditório. É convite, portanto, para a definição tanto da identidade do orador quanto do auditório. Por isso, Aristóteles define que é preciso entender: (a) quais são as disposições das pessoas, qual é a disposição, por exemplo, de alguém em cólera. Então, (b) contra quem normalmente se encoleriza e (c) por qual motivo. ${ }^{29}$

Pathos é, para Meyer, "o próprio conceito do desdobramento, da diferença irredutível, do drama possível". ${ }^{30}$ Para o discurso, é a potência do auditório. Se o discurso evocar o amor no auditório, como esse auditório reagirá a ele? A quais experiências será remetido? Os discursos que louvam o "até que a morte nos separe" com certeza não são eficazes para aqueles que buscam a felicidade por outras vias, seja pela religião, pelo trabalho ou pela pátria. O pathos é a diferença entre orador e auditório. Meyer propõe, então, que as paixões sejam

\footnotetext{
27 Aristóteles, 2000, p. 5

28 Meyer, 2000, p. XXI

29 Figueiredo e Santos Júnior (2020) apresentam como cada paixão citada por Aristóteles é descrita a partir desses três itens

30 Meyer, 2000, p. XXXV
} 
observadas a partir da imagem que os outros criam a nosso respeito. $\mathrm{O}$ amor, por exemplo, é o lugar da associação com o outro.

É a partir dessas reflexões que analisamos a música "Pequenas Alegrias da Vida Adulta", do rapper Emicida. Com base em Galinari (2014), Meyer (2000) e Ferreira (2019), construímos os seguintes pontos de análise: 1) o logos: a) sua complexidade estrutural, b) seu vínculo com os saberes partilhados, c) a sua figuração em determinado contexto, d) sua tese, e) a sua eficácia em adesões intelectuais (fazer-crer), comportamentais (fazer-fazer) e emotivas (fazer-sentir); 2) o ethos: a) sua instância individual ou coletiva, b) sua personalidade, c) seu caráter (phrónesis, areté e eúnoia), d) sua importância ao reforçar a tese; e 3) o pathos: a) as paixões despertadas pelo logos, b) as disposições de quem sente a paixão, c) contra quem se sente, d) o motivo pelo qual se sente, e) sua importância ao reforçar a tese. Passamos, com isso, à análise.

\section{Pequenas Alegrias da Vida Adulta: análise}

Apresentamos a letra de "Pequenas Alegrias da Vida Adulta", terceira música do álbum AmarElo de Emicida:

$\begin{array}{ll}\text { 1. } & \text { Deve-se ter cuidado ao passar no trapézio } \\ \text { 2. } & \text { Me(s)mo que pese o desespero dos novos tempos } \\ \text { 3. } & \text { Se um like serve ao ódio, bro, nesse episódio } \\ \text { 4. } & \text { Breve, o bom senso diz: respire um momento } \\ \text { 5. } & \text { E sobre aprender, tipo giz e lousa } \\ \text { 6. } & \text { O espírito repousa, reza e volta cem por cento } \\ \text { 7. } & \text { Cale tudo que o mundo fale e pense } \\ \text { 8. } & \text { Enquanto a vida vale } \\ \text { 9. } & \text { Seja luz nesse dia cinzento } \\ \text { 10. } & \text { E ela diz “Deus te acompanhe, pretin', bom dia” } \\ \text { 11. } & \text { Me deu um beijo e virou poesia } \\ \text { 12. } & \text { "Deus te acompanhe, pretin'” } \\ \text { 13. } & \text { E um lampejo de amor explodiu em alegria } \\ \text { 14. } & \text { Deus te acompanhe, pretin' } \\ \text { 15. } & \text { Volta pra nós como camisa } 10 \text { após o gol } \\ \text { 16. } & \text { Meu peito rufla, o olho brilha, isso é ter uma família } \\ \text { 17. } & \text { Minha alma disse demorô } \\ \text { 18. } & \text { Então eu vou bater de frente com tudo por ela } \\ \text { 19. } & \text { Topar qualquer luta } \\ \text { 20. } & \text { Pelas pequenas alegrias da vida adulta } \\ \text { 21. } & \text { (Eu vou) Eu vou pro fronte como guerreiro } \\ \text { 22. } & \text { Nem que seja pra enfrentar o planeta inteiro }\end{array}$




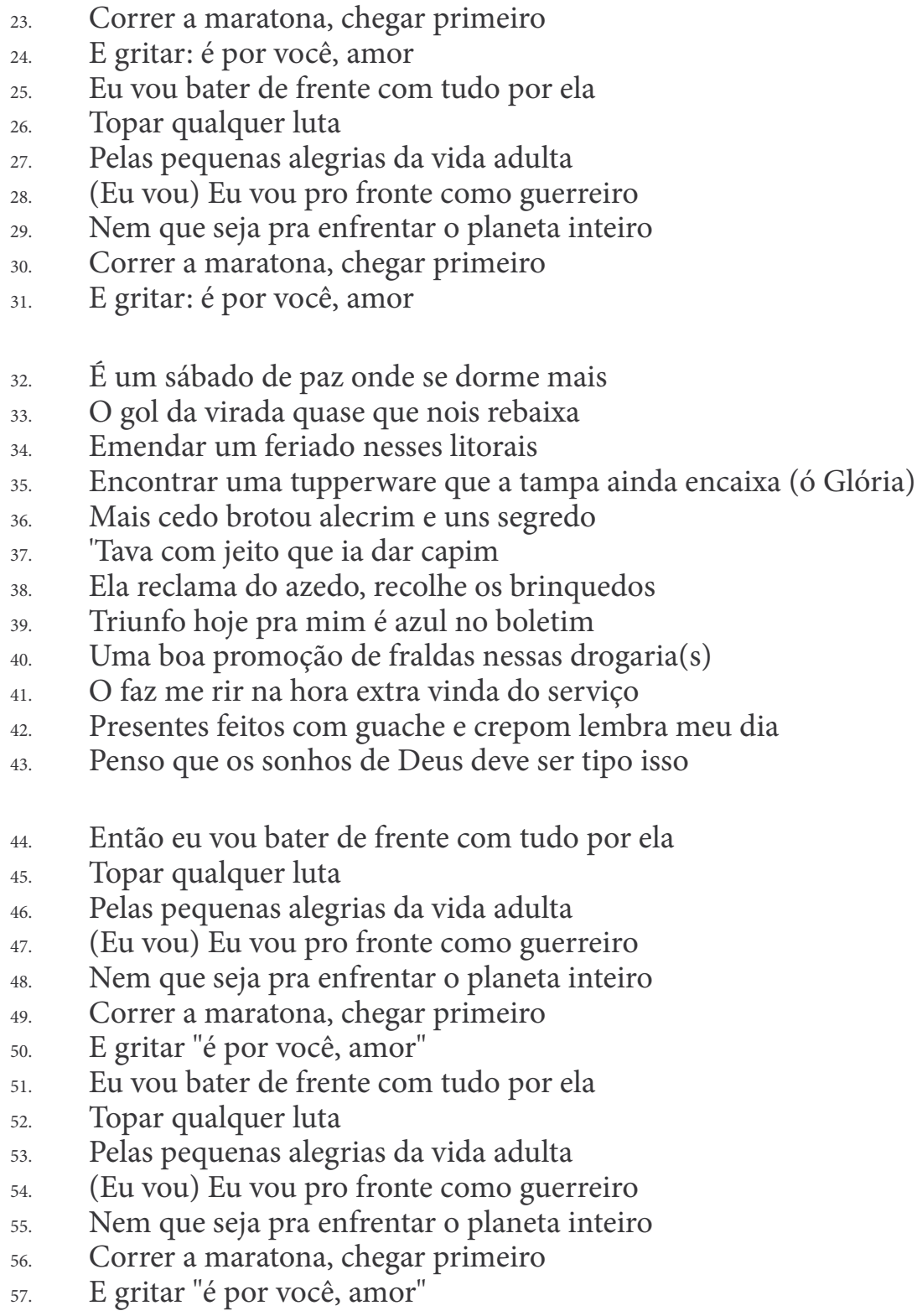

O discurso divide-se em cinco partes. Consideramos a primeira, o exórdio, as linhas 1 a 17, o seu objetivo é introduzir o tema do discurso e estabelecer a identificação entre auditório e orador. A primeira linha apresenta uma metáfora: o trapézio é a segurança em meio ao salto do acrobata ("deve-se ter cuidado ao passar no trapézio"). É assim representada a saída diária para o trabalho, quan- 
do deixamos a segurança da casa para o desconhecido da rua. Essa suposição se confirma com a despedida enunciada em "E ela diz 'Deus te acompanhe, pretin', bom dia" e "Volta pra nós como camisa 10 após o gol". A presença da segurança e da insegurança na rotina se justifica pelo uso do vocativo "pretin". Temos, então, um saber partilhado: o cotidiano urbano é pontuado de violências para a população negra no Brasil. O "desespero dos novos tempos" e o "like" nos remetem a essa realidade discursiva construída a partir das redes sociais. Nelas, os ânimos se acirram e o ódio é latente. A música, como antídoto a esse movimento que contamina os laços pessoais, oferece um caminho: "Se um like serve ao ódio, bro, nesse episódio/ Breve, o bom senso diz: respire um momento". Está aqui a tese: em meio ao desespero, é preciso ter calma. Dado o contexto de polarização social, a música se realiza em um momento oportuno (kairos).

Uma vez introduzido o tema, o discurso, ainda no exórdio, busca a identificação entre orador e auditório. Observamos, a partir de Ferreira (2019), a phrónesis (prudência), a areté (virtude) e a eúnoia (benevolência). Nas linhas 3 e 4, percebemos a prudência, já que buscar a calma diante das adversidades é a atitude do homem prudente ("bom senso"). Temos, então, a primeira pista sobre o gênero do discurso: "É sobre aprender, tipo giz e lousa", que reforça o caráter educador do epidítico. Por outro lado, emprega-se o modo imperativo em "deve", "respire", "cale", "pense" e "seja". Embora aconselhar seja uma caraterística do gênero deliberativo, é natural a predominância do gênero não ser absoluta, conforme Ferreira (2010). O primeiro e o segundo conselhos ("O espírito repousa, reza e volta cem por cento", "Cale tudo que o mundo fale e pense/ Enquanto a vida vale”) são prudentes por demonstrar atitude razoável: buscar a calma diante do caos. Ao argumentar pela razoabilidade, evoca-se a parte racional da alma. Já o último ("Seja luz nesse dia cinzento") apela a eúnoia: o orador coloca-se como benevolente e solidário ao ser a alegria do outro, por estar a serviço.

Falta-nos a areté, a virtude. Como nos aponta Ferreira (2019), areté é a virtude que se realiza quando o homem encontra a justa medida. Assim, "o virtuoso não se mostra covarde (vício por falta) ou temerário (vício por excesso), pois conhece a justa medida entre esses dois vícios e encontra, na coragem, o meio termo favorável para seus propósitos" ${ }^{31}$ A coragem, para Aristóteles (Retórica, Livro I), "é a virtude que habilita os homens a realizar nobres ações em situações de perigo, de acordo com a lei e a serviço dela". ${ }^{32} \mathrm{O}$ discurso apresenta, nas linhas 10 a 17, um homem que enfrenta os perigos contidos na vida urbana, especialmente da população negra ("pretin"). A coragem é posta ("meu peito

31 Ferreira, 2010, p. 17, grifo nosso

32 Aristóteles, 2011, p. 81 
rufla, o olho brilha”) a partir da família (“isso é ter uma família”). Há também a aceitação da outra parte da alma humana: as paixões. Sem perder a prudência, afinal o homem, racionalmente, deve cuidar daqueles que ama, a alma entra como parte da ação ("minha alma disse demorô").

Por louvar virtudes, colocamos como hipótese a música pertencer ao discurso epidítico, ${ }^{33}$ que "reforça uma disposição para a ação ao aumentar a adesão aos valores que exalta" ${ }^{34}$ Como o orador não espera que o auditório delibere sobre o futuro (gênero deliberativo) ou julgue fatos passados (gênero jurídico), o discurso epidítico volta-se ao presente. Ainda assim, como explicam Perelman e Olbrechts-Tyteca, a ação do auditório, persuadido pelo discurso, não se realiza no tempo presente. Há um lapso entre a adesão ao discurso e a tomada de decisão porque o gênero epidítico insta o auditório a reforçar os valores louvados em ações futuras.

O refrão da música (18 a 31) é a narração, a exposição dos argumentos do discurso. Como vimos, o discurso epidítico busca a adesão a valores. A primeira parte, as linhas 18 a 23, apresenta as ações desse homem, tido como virtuoso: "vou bater de frente com tudo", "topar qualquer luta", "vou pro fronte" (...) "pra enfrentar o planeta inteiro", "correr a maratona, chegar primeiro". A coragem se desvela, ainda, pelo uso do campo semântico de guerra: "bater", "luta", "fronte", "guerreiro", "enfrentar". Para Aristóteles, as ações "que não são realizadas em vista do próprio interesse" ${ }^{35}$ são nobres e, por isso, virtuosas. Confirma-se, assim, não só a demonstração de virtude, como também da benevolência do orador.

A segunda parte da narração apresenta a motivação do orador: "E gritar “é pra você amor”" Por ser uma música, o auditório, primeiro, não saberá se o "amor", aqui, é vocativo ou aposto. A motivação é, então, a mulher ou o próprio amor? Essa ambiguidade é desfeita em seguida: "eu vou bater de frente com tudo por ela”. Se considerarmos as reflexões acerca do amor já feitas, podemos identificar o tipo de amor exortado pelo discurso. É o amor digno, virtuoso, nobre, que gerou filhos pelo impulso de criação. Contrariando, de certa forma, a nossa cultura do consumo, a música retrata um amor que constrói e se realiza na rotina. A busca pela felicidade é retratada a partir de momentos cotidianos.

A confirmação do discurso (linhas 32 a 42), a reafirmação das provas, é feita pelo uso de ilustração, em que "é comum a tendência de nela ver uma imagem"."36

33 Ressaltamos que a retórica divide os gêneros oratórios em três: deliberativo, judiciário e epidítico. O último, nos escritos retóricos, é muitas vezes tido como um gênero menor. Conforme Ferreira (2020), o epidítico é visto como o mais fácil dos gêneros. Sendo assim, se o orador aprendesse os dois primeiros, naturalmente também o dominaria

34 Perelman; Olbrechts-Tyteca, 2014, p. 54

35 Aristóteles, 2011, p. 82

36 Perelman; Olbrechts-Tyteca, 2014, p. 410 
De acordo com Perelman e Olbrechts-Tyteca, a escolha da ilustração é movida pela sua repercussão afetiva. De fato, vemos um apelo à sensibilidade do auditório quando, pela ativação de memórias, a felicidade é retratada: "É um sábado de paz onde se dorme mais", "O gol da virada quase que nois rebaixa", "Emendar um feriado nesses litorais", "Encontrar uma tupperware que a tampa ainda encaixa (ó Glória)", "Ela reclama do azedo, recolhe os brinquedos", "Triunfo hoje pra mim é azul no boletim", "Presentes feitos com guache e crepom lembra meu dia". Destacamos, ainda, que o emprego de "brinquedos", "boletim", "fralda", "guache" e "crepom" nos remete à criação de filhos. As ilustrações descrevem casos particulares para concretizar uma regra: as pequenas alegrias se encontram na rotina. O discurso confirma, portanto, que o amor não é construído em grandes atos, mas no envolvimento com a vida doméstica.

Aqui, mais claramente, percebemos a imagem do auditório da música. Uma vez que busca adesão, o orador cria imagens conhecidas pelo seu público. Quem, então, sentiria calma a partir dessas ilustrações? Dormir mais aos sábados, um dia de folga para a maioria, não é em si um grande luxo. Além disso, e certamente, apenas a classe trabalhadora considera como alegria "uma boa promoção de fraldas nessas drogaria(s)" ou "o faz me rir na hora extra vinda do serviço". Aliás, a expressão "faz me rir", por si só, conversa diretamente com o trabalhador assalariado. Temos, então, como imagem do auditório, pessoas de centros urbanos ("drogaria(s)") em um cenário de insegurança econômica, em que se vive um salário de cada vez.

Por fim, a peroração (linhas 43 a 57), a parte final do discurso, pode se dividir em três: recapitulação, apelo ao pathos, e amplificação. A última está na linha 43, é uma extrapolação da maior felicidade possível ("Penso que os sonhos de Deus deve ser tipo isso"). A repetição do refrão, então, funciona como recapitulação ao reapresentar o amor e a coragem. A música louva, assim, a rotina. A motivação, aquilo que desperta a coragem, se traduz em "Topar qualquer luta pelas pequenas alegrias da vida adulta". O apelo ao pathos, por último, está no despertar do amor ("E gritar 'é por você, amor").

Concluímos essa primeira parte, dedicada ao logos, com uma breve retomada dos pontos elencados para análise. A complexidade estrutural do logos foi descrita a partir de criação de ilustrações, exploração da ambiguidade com o vocativo/aposto, uso do modo imperativo ao aconselhar, emprego de sintagmas verbais para descrever as ações do orador, e exploração do campo semântico de guerra. Sobre o contexto desse discurso, o exórdio estabelece como ponto de partida para orador e auditório que as redes sociais reforçaram as diferenças entre as pessoas. As redes representam um avanço tecnológico que, como tantos outros, geraram impacto não só na comunicação interpessoal como também na de massas. Vivemos uma adaptação a um novo formato de interação. O dis- 
curso oferece, então, um antídoto ao ódio: "Se um like serve ao ódio, bro, nesse episódio/ Breve, o bom senso diz: respire um momento" (tese).

Observamos, por fim, o potencial de eficácia do logos. A adesão intelectual (fazer-crer) se apoia nas ilustrações que, por sua vez, apelam à adesão emotiva (fazer-sentir). As sensações despertadas por elas funcionam como recompensa por se exercer a prudência. O caráter do orador, que revela as suas virtudes pelas ações, cria a adesão comportamental (fazer-fazer). Aristóteles postula que "o louvor é um discurso que exibe a grandeza da virtude. (...) é necessário mostrar que os atos são bons produtos da virtude". ${ }^{37}$ Consideramos, portanto, "Pequenas Alegrias da Vida Adulta" como discurso epidítico.

O ethos retratado é individual, já que as ilustrações retratam casos particulares. Temos um homem relatando situações compartilhadas com a sua família. A sua motivação parte da mulher: "E gritar "é por você, amor" e "Eu vou bater de frente com tudo por ela". Se observamos o orador como pai, no entanto, apelamos para uma identidade coletiva. Ser motivado pelo amor conjugal ou pelo amor parental, de qualquer forma, representa o amor. Observamos, ainda, uma recriação dessa representação. As produções culturais costumam evidenciar a representação do amor como desejo, um impulso de consumir o outro. A música, por outro lado, louva o amor construído pela coragem e pela humildade. Os momentos cotidianos demonstram, para isso, phrónesis (prudência), areté (virtude) e eúnoia (benevolência) no exórdio. O genérico epidítico enfatiza que as ações do orador derivam da sua própria virtude. Assim, o discurso nos apresenta a imagem de um homem virtuoso. Há, no entanto, uma atualização dessa identidade.

Historicamente, o homem é representado como economicamente responsável pela família, mas é a mulher quem se dedica aos cuidados cotidianos. As produções artísticas, normalmente, exaltam, como virtude dos "homens tradicionais", a coragem, a moderação, a generosidade, a prudência e a sabedoria. A música analisada reforça as mesmas virtudes, mas representadas de uma nova maneira. Amplia-se, assim, a caracterização de um homem bom ainda que as virtudes sejam as mesmas: a coragem ("Eu vou bater de frente com tudo por ela/ Topar qualquer luta"), a moderação ("Deve-se ter cuidado ao passar no trapézio"), a generosidade ("Seja luz nesse dia cinzento"), a prudência ("Breve, o bom senso diz: respire um momento") e a sabedoria ("O espírito repousa, reza e volta cem por cento"). A identificação entre orador e auditório se constrói, ainda, pelo envolvimento com os afazeres do dia a dia ("Encontrar uma tupperware que a tampa ainda encaixa"), o companheirismo ("Ela reclama do azedo, recolhe

37 Aristóteles, 2011, p. 86 
os brinquedos"), a educação dos filhos ("Triunfo hoje pra mim é azul no boletim"), e o amor ("Presentes feitos com guache e crepom lembra meu dia"). Essa representação de masculinidade destaca, ainda, o papel do homem no sustento da família ("O faz me rir na hora extra vinda do serviço").

O discurso busca uma adesão emotiva (fazer-sentir) a partir das sensações despertadas no auditório. Dentre as paixões aristotélicas, a música busca despertar a calma e o amor no auditório. A calma, para Meyer, recria a simetria e conduz à virtude da temperança. Aristóteles exemplifica quando sentimos calma: "as pessoas são calmas, como, por exemplo, no jogo, no riso, na festa, num dia feliz, num momento de sucesso, na realização dos desejos e, em geral, na ausência da dor, no prazer inofensivo e na esperança justa". ${ }^{38}$ Já o amor, para Meyer, é o lugar da associação com o outro: "o amor, ou a amizade, é certamente um vínculo de identidade mais ou menos parcial. (...) A distância entre os indivíduos se revela insignificante." 39 Aristóteles enumera quem amamos: "os que louvam as qualidades que possuímos e, entre essas, aquelas que sobretudo receamos não ter" ${ }^{40}$

As linhas 1 a 9, parte do exórdio, despertam a calma. O conselho "Deve-se ter cuidado ao passar no trapézio" demonstra o cuidado, a benevolência, do orador. Não há tensão entre orador e auditório, pelo contrário, o exórdio concentrase em evocar o bom senso ("Breve, o bom senso diz: respire um momento"). Observamos, ainda, a calma exortada como uma virtude, a temperança: "O espírito repousa, reza e volta cem por cento". Essa calma, resposta ao ódio das redes sociais, evoca o amor, exórdio e narração (linhas 10 a 31). Essa sensação é responsável pela identificação entre orador e auditório, pela diminuição da distância. $\mathrm{O}$ auditório do discurso, então, é composto por quem acredita que o amor é a busca pela felicidade. A confirmação (linhas 32 a 42) e a primeira parte da peroração (linha 43), novamente, buscam a calma: "um sábado de paz", "um feriado", "ó Glória", "triunfo", "sonhos", "Deus". Temos o retrato de experiências compartilhadas entre orador e auditório. Em meio a tantos discursos que nos dividem, "Pequenas Alegrias da Vida Adulta" descreve as experiências que compartilhamos. O final da peroração, por ser a repetição do refrão, é novamente um apelo ao amor. 


\section{Amor: considerações finais}

A busca pela compreensão do amor é constante. É um sentimento, uma emoção, uma justificativa, um motivo, uma ambição, uma aspiração, um deus. Amamos profundamente pessoas com quem dividimos momentos importantes da nossa história. E assim, multifacetado, o amor cria elos diferentes entre amigos, amantes e parentes. Como já provamos do amor, de uma forma ou de outra, temos uma compreensão sobre ele a partir de experiências vividas. Por isso, para estudar o amor, é preciso se distanciar dele, um movimento difícil já que o amor nos é tão caro.

A primeira seção deste artigo conceituou o amor a partir de Platão (2010), importante teórico para os estudos retóricos, Bauman (2004), notável sociólogo moderno, e Martuccelli (2016), professor de sociologia da Universidade ParisDescartes (Sorbonne). A partir das leituras, pretendemos compreender se as definições de amor em Platão (2010) ecoam, de alguma maneira, nos textos dos sociólogos ou se estamos diante de uma ruptura total entre o que chamamos de amor e a sua concepção há mais de dois mil anos. Encontramos semelhanças quanto à dualidade do amor: o nobre e o vil e à definição do amor pela morte. Bauman (2004) argumenta, ainda, que uma sociedade consumista se inclina a tomar o desejo pelo amor. Martuccelli (2016), no entanto, observa a existência de produções que optam por imaginar um outro retrato do amor, um possível e destinado à manutenção da vida em sociedade como forma coletiva.

"Pequenas Alegrias da Vida Adulta" parece-nos um louvor ao amor, tal qual os discursos de "O Banquete". Esse discurso, como gênero epidítico, defende as virtudes necessárias a uma representação de homem. A adesão intelectual (fazer-crer) se realiza quando orador e auditório se identificam com as mesmas virtudes: coragem, moderação, generosidade, prudência e a sabedoria. Ao retratar cenas cotidianas, busca a adesão emotiva (fazer-sentir) pelo despertar da calma e do amor. Por fim, o auditório, se persuadido, deve buscar realizar ações tão nobres quanto as do orador (fazer-comportamental).

\section{Referências}

ARISTÓTELES. Retórica das paixões. Tradução de Isis Borges da Fonseca. Prefácio, Michael Meyer. São Paulo: Martins Fontes, 2000.

. Retórica. Tradução, textos adicionais e notas de Edson Bini. São Paulo: Edipro, 2011. BAUMAN, Z. Amor Líquido. Trad. Carlos Alberto Medeiros. Rio de Janeiro: Zahar, 2004. EMICIDA. Triunfo. 2008. Disponível em: https://www.youtube.com/watch?v=YMJOmIuUwiM Acesso em 15 out. 2020 
EMICIDA. Pequenas Alegrias da Vida Adulta. 2019a Disponível em: https://www.youtube. com/watch?v=RVZCB3 011c Acesso em 15 out. 2020

EMICIDA. Emicida faz disco reflexivo e diz se arrepender das atitudes de ódio. [31 de outubro, 2019b] São Paulo: Folha de S.Paulo. Entrevista concedida a Lucas Brêda. Disponível em: https://www1.folha.uol.com.br/ilustrada/2019/10/emicida-faz-disco-reflexivo-e-dizse-arrepender-das-atitudes-de-odio.shtml Acesso em 25 de outubro de 2020

FERREIRA, L. A. Leitura e persuasão: princípios de análise retórica. São Paulo: Contexto, 2010.

. Inteligência retórica e vocalidade: constituição e manutenção do ethos In:

(Org.) Inteligência retórica: o ethos. São Paulo: Blucher, 2019.

. Sobre o prazer e a dor de ser: efeitos patéticos no discurso epidítico. In:

(Org.) Inteligência retórica: o pathos. São Paulo: Blucher, 2020.

FIGUEIREDO, M. F.; SANTOS JÚNIOR, V. F. Uma incursão ao pathos: método aristotélico de descrição das paixões e a relação hierárquica delas emanada. In: FERREIRA, L. A. (Org.) Inteligência retórica: o pathos. São Paulo: Blucher, 2020.

GALINARI, M. M. Logos, ethos e pathos: "três lados" da mesma moeda. Alfa, São Paulo, n. 58 (2), p. 257-285, 2014.

MARTUCCELLI, D. O indivíduo, o amor e o sentido da vida nas sociedades contemporâneas. Estudos Avançados. São Paulo, vol. 30 (86), p. 147-165, 2016.

MEYER, M. As paixões nos diálogos platônicos. In: ARISTÓTELES. Retórica das paixões. Tradução de Isis Borges da Fonseca. São Paulo: Martins Fontes, 2000.

What is rhetoric? Oxford: Oxford University Press, 2017.

NUSSBAUM, M. A fragilidade da bondade: fortuna e ética na tragédia e na filosofia grega. Trad. Ama Aguiar Cotrim; revisão da tradução Aníbal Mari. São Paulo: Editora WMF Martins Fontes, 2009.

PERELMAN, C.; OLBRECHTS-TYTECA, L. Tratado de argumentação: a nova retórica. 3. ed. São Paulo: Martins Fontes, 2014.

PLATÃO. Diálogos V: O Banquete; Mênon (ou Da Virtude); Timeu; Crítias. Tradução, textos adicionais e notas de Edson Bini. Bauru/SP: Edipro, 2010.

. Diálogos II: Górgias (ou Da Retórica); Eutidemo (ou Da Disputa); Hípias Maior

(ou Do Belo); Hípias Menor (ou Do Falso). Tradução, textos adicionais e notas de Edson Bini. São Paulo: Edipro, 2016.

PUENTES, F. R. A téchne em Aristóteles. Hypnos. São Paulo, no 4, p. 129-135, 1998

TELLA, M. A. P. Atitude, arte, cultura e autoconhecimento: o rap como voz da periferia. 2000. Dissertação (Mestrado em Ciências Sociais) - Pontifícia Universidade Católica de São Paulo, São Paulo. 